\title{
OCENA WYSTĘPOWANIA STRESU W GRUPIE PIELEEGNIAREK ZATRUDNIONYCH W SAMODZIELNYM PUBLICZNYM SZPITALU KLINICZNYM IM. PROF. WITOLDA ORŁOWSKIEGO W WARSZAWIE
}

\section{ASSESSMENT OF STRESS INCIDENCE AMONG NURSES OF PROFESSOR WITOLD ORtOWSKI INDEPENDENT PUBLIC CLINICAL HOSPITAL}

\author{
Marta Burba', Joanna Gotlib² \\ ${ }^{1}$ Pielęgniarstwo \\ Warszawski Uniwersytet Medyczny \\ ${ }^{2}$ Zakład Dydaktyki i Efektów Kształcenia \\ Warszawski Uniwersytet Medyczny
}

DOI: https://doi.org/10.20883/pielpol.2017.7

\begin{abstract}
STRESZCZENIE
Wstęp i cel. Osoby wykonujące zawody medyczne są najbardziej narażone na występowanie stresu i wypalenia zawodowego. Celem pracy była analiza wpływu stażu pracy na występowanie stresu w grupie pielęgniarek zatrudnionych w Samodzielnym Publicznym Szpitalu Klinicznym im. prof. Witolda Orłowskiego w Warszawie.

Materiał i metody. W badaniach udział wzięło 100 pielęgniarek (100\% kobiet). Średni wiek: 39,3 roku (SD = 15,22, min. 24, maks. 60). Średni staż pracy: 16,2 roku (SD = 9,73, min. 1, maks. 37). Metodami badawczymi były: dobrowolne i anonimowe badania ankietowe, narzędzia to: Skala Odczuwanego Stresu (PSS-10), Inwentarz do Pomiaru Radzenia Sobie ze Stresem (Mini Cope) oraz własny kwestionariusz. Analiza statystyczna została przeprowadzona za pomocą programu STATISTICA 12.5, licencja Warszawskiego Uniwersytetu Medycznego, test statystyczny Kruskala-Wallisa, $\alpha<0,05$.

Wyniki. Większość (84\%) deklarowała, że stres jest nieodłącznym elementem zawodu pielęgniarki, a czynnikami najbardziej stresującymi są: praca pod presją czasu oraz odpowiedzialność za życie i zdrowie pacjenta. Spośród badanych $56 \%$ deklarowało, że pielęgniarki często spotykają się z przemocą i mobbingiem (58\%). Aż $65 \%$ stwierdziło, że odczuwa bóle kręgosłupa z powodu stresu. W badanej grupie $31 \%$ pielęgniarek deklarowało, że podejmuje działania mające na celu zmniejszenie stresu. 0 paleniu papierosów, traktowanym jako jeden z najczęstszych sposobów radzenia sobie ze stresem, mówiło $65 \%$ respondentek.

Wnioski.
\end{abstract}

1. W badanej grupie pielęgniarek stwierdzono średni poziom odczuwanego stresu, a pielęgniarki z krótszym stażem pracy istotnie częściej odczuwały stres.

2. W konfrontacji z trudnymi sytuacjami w pracy zawodowej badane pielegniarki stosowały konstruktywne sposoby radzenia sobie ze stresem, które polegały na analizie i wypracowaniu określonych działań zmierzających do rozwiązania problemu.

3. Wodreagowaniu napięć związanych z pracą pielęgniarki preferują negatywne sposoby radzenia sobie ze stresem, tj. palenie papierosów oraz objadanie się. Wykazują zaś nikłą wiedzę na temat profesjonalnych technik rozładowujących stres.

\begin{abstract}
Introduction and aim. Health professionals are most vulnerable to stress and burnout. The study aimed to analyse the influence of the length of service on the incidence of stress among nurses of Professor Witold Orłowski Independent Public Clinical Hospital in Warsaw.

Material and methods. A total of 100 nurses, women constituted $100 \%$ of all. Mean age: 39.3 years ( $S D=15.22$, min. 24 , max. 60 ). Mean length of service was 16.2 years $(S D=9.73$, min. 1 , max. 37). A voluntary and anonymous questionnaire study, the following research tools: Perceived Stress Scale (PSS-10), Inventory for Measuring Coping with Stress (Mini Cope), and original questionnaire. Statistical analysis: STATISTICA 12.5 licensed to Warsaw Medical University, Kruskal-Wallis statistical test, $\alpha<0.05$.

Results. Most study participants (84\%) said that stress was an intrinsic part of the nursing profession and working under pressure of time as well as the responsibility for the life and health of patients were among the most significant stress factors. $56 \%$ of the respondents said that nurses often faced violence and mobbing (58\%). $65 \%$ of the study participants experienced back pain due to stress. $31 \%$ of the nurses took action to reduce stress. According to $65 \%$ of the total smoking was the most popular way of dealing with stress.

Conclusions.

1. The study group of nurses demonstrated a medium level of stress and nurses with shorter length of service experienced stress significantly more often.

2. In difficult situations at work the nurses used constructive ways of dealing with stress, including an analysis of a problem and development of specific actions to resolve the issue.

3. To release stress related to work, the nurses chose negative ways of coping with stress such as smoking and overeating. They also had little knowledge of stress management techniques.
\end{abstract}




\section{Wstęp}

Praca zawodowa jest jedną z najważniejszych form działalności człowieka [1-3]. Może ona oddziaływać na niego pozytywnie, ale może być również źródłem psychicznego dyskomfortu i frustracji [4-7].

Stres w pracy zawodowej oraz przeciążenia zarówno psychiczne, jak i fizyczne powodują spadek motywacji, bezradność, a nawet chorobę. Ważne jest to, jakie czynniki i okoliczności mogą wywołać stres. Jeśli stawiane żądania są w granicach możliwości człowieka, stres jest zjawiskiem pozytywnym, nazywanym eustresem, natomiast jeśli przekraczają ludzkie możliwości, stres staje się czymś negatywnym - dystresem [7].

Osoby wykonujące zawody medyczne, np. pielęgniarki, narażone są na oddziaływanie różnych czynników stresogennych, związanych z ochroną zdrowia i ratowaniem życia pacjentów. Najpoważniejszym skutkiem występowania stresu w pracy pielęgniarki może być zespół wypalenia zawodowego, prowadzący do przedmiotowego traktowania pacjentów, a nawet porzucenia zawodu [8, 9].

W ostatnich latach wzrosło zainteresowanie występowaniem stresu w środowisku pracy pielęgniarek. Temat ten poruszany jest w wielu publikacjach w polskim i światowym piśmiennictwie naukowym [1-9].

\section{Cel pracy}

Celem pracy była analiza wpływu stażu pracy na występowanie stresu w grupie pielęgniarek zatrudnionych w Samodzielnym Publicznym Szpitalu Klinicznym im. prof. Witolda Orłowskiego w Warszawie.

\section{Materiał i metody}

\section{Materiał}

W badaniach udział wzięło 100 pielęgniarek (100\% kobiet) zatrudnionych w oddziałach klinicznych: okulistyki, neurologii i epileptologii, medycyny rodzinnej, chirurgii ogólnej, neonatologii, bloku operacyjnym oraz w przychodni specjalistycznej w Samodzielnym Publicznym Szpitalu Klinicznym im. prof. Witolda Orłowskiego w Warszawie. Średni wiek ankietowanych kobiet wynosił 39,3 roku (SD = 15,22, min. 24, maks. 60). Średni staż pracy wyniósł 16,2 roku (SD = 9,73, min. 1, maks. 37).

Badaną grupę pielęgniarek podzielono na cztery grupy w zależności od stażu pracy. Grupę 1 stanowiły pielęgniarki ze stażem pracy 0-10 lat, grupę 2 - pielęgniarki ze stażem 11-20 lat, grupę 3 - pielęgniarki ze stażem 21-30 lat i grupę 4 - pielęgniarki ze stażem pracy powyżej 30 lat.

\section{Metody}

Dobrowolne i anonimowe badania ankietowe przeprowadzono w dniach od 10 stycznia do 28 lutego 2013 r.
W przeprowadzonych badaniach wykorzystano standaryzowane narzędzia pomiarowe do pomiaru poziomu stresu: Skalę Odczuwanego Stresu (PSS-10), Inwentarz do Pomiaru Radzenia Sobie ze Stresem (Mini Cope) oraz własny kwestionariusz.

Skala Odczuwanego Stresu PSS-10 została stworzona przez Cohena, Kamracka i Mermelseina w 1983 r. Adaptacji kwestionariusza do polskich warunków dokonali Juczyński i Ogińska-Bulik w 2009 r. Skala Odczuwanego Stresu miała na celu ocenę subiektywnych odczuć dotyczących stresu doznawanego w pracy przez pielęgniarki. Każde pytanie zaczynało się od sformułowania ,Jak często w ciągu ostatniego miesiąca ...", pielęgniarka sama oceniała częstość występowania każdego zdarzenia, gdzie 0 oznaczało: nigdy, 1 - prawie nigdy, 2 - czasem, 3 - dość często, 4 - bardzo często. Wynik dla każdego pytania mógł wynieść od 0 do 4 punktów, a wynik ogólny wynosił od 0 do 40 punktów; im wyższy wynik punktowy, tym wyższy poziom stresu u pielęgniarki [10].

Inwentarz do Pomiaru Radzenia Sobie ze Stresem (Mini Cope) opracowany został przez Carvera do pomiaru różnych strategii radzenia sobie ze stresem. Adaptacji do polskich warunków dokonali Juczyński i Ogińska-Bulik w 2009 r. Wersja w języku polskim funkcjonuje jako Mini Cope [11]. Mini Cope zawiera 28 zdań charakterystycznych dla danego sposobu radzenia sobie ze stresem. Badane pielęgniarki oceniały twierdzenia dotyczące zachowania się w trudnej sytuacji w skali od 0 do 3, gdzie 0 oznaczało: prawie nigdy tak nie postępuję, 1 - rzadko tak postępuję, 2 - często tak postępuję, 3 - prawie zawsze tak postępuję [11].

Samodzielnie stworzony kwestionariusz składał się z 38 pytań, pierwszą część kwestionariusza stanowiła metryczka, czyli pytania dotyczące: stanu cywilnego, wieku, stażu i miejsca pracy, charakteru wykonywanej pracy oraz wykształcenia. Kwestionariusz zwierał 25 pytań zamkniętych jednokrotnego wyboru oraz 7 pytań wielokrotnego wyboru.

\section{Analiza statystyczna uzyskanych wyników}

Uzyskane w wyniku przeprowadzonych badań dane zostały zdigitalizowane w arkuszu Microsoft Excel 2007 (Microsoft Office).

Analizę statystyczną uzyskanych wyników przeprowadzono w Zakładzie Dydaktyki i Efektów Kształcenia Wydziału Nauki o Zdrowiu Warszawskiego Uniwersytetu Medycznego. W związku z tym, że porównywano cztery niezależne grupy oraz ze względu na charakter analizowanych danych (dane jakościowe, nieparametryczne), do analizy statystycznej uzyskanych wyników wykorzystano nieparametryczny test statystyczny Kru- 
skala-Wallisa, za istotny przyjęto poziom istotności statystycznej $\alpha<0,05$.

\section{Wyniki}

Zdecydowana większość badanych (84\%) deklarowała, że stres jest nieodłącznym elementem zawodu pielęgniarki. Szczegółowe dane dotyczące występowania stresu w pracy zawodowej w badanej grupie pielęgniarek przedstawia tabela 1.

Tabela 1. Występowanie stresu w pracy zawodowej w badanej grupie pielęgniarek

Table 1. Incidence of work-related stress among nurses

\begin{tabular}{|c|c|c|c|}
\hline Pytanie/Question & & $\begin{array}{c}\text { Cała grupa/ } \\
\text { The entire } \\
\text { group } \\
\mathrm{n}=100\end{array}$ & $p$ \\
\hline \multirow{5}{*}{$\begin{array}{l}\text { Chęć chodzenia do pracy/ } \\
\text { Enthusiasm for work }\end{array}$} & $\begin{array}{l}\text { zdecydowanie tak/ } \\
\text { strongly yes }\end{array}$ & 16 & \multirow{5}{*}{$p<0,00$} \\
\hline & raczej tak/rather yes & 42 & \\
\hline & tak/yes & 19 & \\
\hline & raczej nie/rather not & 19 & \\
\hline & nie/no & 4 & \\
\hline \multirow{5}{*}{$\begin{array}{l}\text { Odczuwanie stresu/ } \\
\text { Experience of stress }\end{array}$} & codziennie/every day & 41 & \multirow{5}{*}{$p<, 000$} \\
\hline & $\begin{array}{l}\text { raz w tygodniu/ } \\
\text { once a week }\end{array}$ & 24 & \\
\hline & $\begin{array}{l}\text { kilka razy w tygodniu/ } \\
\text { several times a week }\end{array}$ & 21 & \\
\hline & $\begin{array}{l}\text { raz w miesiącu/ } \\
\text { once a month }\end{array}$ & 12 & \\
\hline & nigdy/never & 2 & \\
\hline \multirow{3}{*}{$\begin{array}{l}\text { Stres jako nieodłączny } \\
\text { element zawodu pie- } \\
\text { lęgniarki/Stress as an } \\
\text { intrinsic part of nursing } \\
\text { profession }\end{array}$} & tak/yes & 84 & \multirow{3}{*}{$p<, 000$} \\
\hline & nie/no & 12 & \\
\hline & $\begin{array}{l}\text { nie mam zdania/ } \\
\text { no opinion }\end{array}$ & 4 & \\
\hline
\end{tabular}

$\mathrm{p}$ - poziom istotności różnic pomiędzy badanymi grupami pielęgniarek w zależności od stażu pracy/level of significance of differences between study subgroups of nurses by length of service

Źródło: opracowanie własne

Source: author's own analysis

Większość badanych pielęgniarek deklarowała, że czynnikami najbardziej stresującymi w pracy pielęgniarki są: praca pod presją czasu oraz odpowiedzialność za życie i zdrowie pacjenta. Szczegółowe dane dotyczące występowania czynników stresogennych w pracy zawodowej w badanej grupie pielęgniarek przedstawia tabela 2.
Tabela 2. Występujące podczas pracy zawodowej czynniki stresogenne w opinii badanych pielęgniarek

Table 2. Work-related stress factors according to the study group of nurses

\begin{tabular}{|c|c|c|c|}
\hline Pytanie/Question & & $\begin{array}{l}\text { Cała grupa/ } \\
\text { The entire } \\
\text { group } \\
\mathrm{n}=100\end{array}$ & $\mathrm{p}$ \\
\hline Hałas/Noise & $\begin{array}{l}\text { tak/yes } \\
\text { nie/no }\end{array}$ & $\begin{array}{l}43 \\
57\end{array}$ & $p<0,679$ \\
\hline $\begin{array}{l}\text { Nieodpowiednie oświetlenie/ } \\
\text { Inadequate lighting }\end{array}$ & $\begin{array}{l}\text { tak/yes } \\
\text { nie/no }\end{array}$ & $\begin{array}{l}29 \\
71\end{array}$ & $p<0,064$ \\
\hline $\begin{array}{l}\text { Wysoka lub niska temperatura/ } \\
\text { High or low temperature }\end{array}$ & $\begin{array}{l}\text { tak/yes } \\
\text { nie/no }\end{array}$ & $\begin{array}{l}20 \\
80\end{array}$ & $\mathrm{p}<, 000$ \\
\hline $\begin{array}{l}\text { Praca zmianowa jako czynnik streso- } \\
\text { genny/Shift work as a stress factor }\end{array}$ & $\begin{array}{l}\text { tak/yes } \\
\text { nie/no }\end{array}$ & $\begin{array}{l}44 \\
56\end{array}$ & $p<0,424$ \\
\hline $\begin{array}{c}\text { Wpływ nieprzyjemnego zapachu na } \\
\text { samopoczucie//nfluence of unpleasant } \\
\text { odour on well-being }\end{array}$ & $\begin{array}{l}\text { tak/yes } \\
\text { nie/no }\end{array}$ & $\begin{array}{l}25 \\
75\end{array}$ & $p<0,424$ \\
\hline $\begin{array}{l}\text { Zagrożenie własnego życia lub zdro- } \\
\text { wia/Risk to own life or health }\end{array}$ & $\begin{array}{l}\text { tak/yes } \\
\text { nie/no }\end{array}$ & $\begin{array}{l}46 \\
54\end{array}$ & $p<0,089$ \\
\hline $\begin{array}{l}\text { Agresywne zachowanie pacjentów/ } \\
\text { Aggressive behaviour of patients }\end{array}$ & $\begin{array}{l}\text { tak/yes } \\
\text { nie/no }\end{array}$ & $\begin{array}{l}36 \\
64\end{array}$ & $p<0,732$ \\
\hline $\begin{array}{l}\text { Praca pod presją czasu/ } \\
\text { Working under pressure of time }\end{array}$ & $\begin{array}{l}\text { tak/yes } \\
\text { nie/no }\end{array}$ & $\begin{array}{l}65 \\
35\end{array}$ & $p<0,426$ \\
\hline $\begin{array}{l}\text { Odpowiedzialność za życie i zdrowie } \\
\text { pacjenta/ } \\
\text { Responsibility for life and health of } \\
\text { patients }\end{array}$ & tak/yes & 82 & $p<0,222$ \\
\hline $\begin{array}{l}\text { Samodzielne i szybkie podejmowanie } \\
\text { decyzji// } \\
\text { Independent and fast decisions }\end{array}$ & $\begin{array}{l}\text { tak/yes } \\
\text { nie/no }\end{array}$ & $\begin{array}{l}46 \\
54\end{array}$ & $p<0,917$ \\
\hline
\end{tabular}

p - poziom istotności różnic pomiędzy badanymi grupami pielęgniarek w zależności od stażu pracy/level of significance of differences between study subgroups of nurses by length of service

Źródło: opracowanie własne

Source: author's own analysis

Szczegółowe dane dotyczące występowania czynników wywołujących stres w pracy zawodowej w badanej grupie pielęgniarek przedstawia tabela 3 .

Tabela 3. Czynniki wywołujące stres w pracy zawodowej badanej grupy pielęgniarek

Table 3. Stress factors at work among the study group of nurses

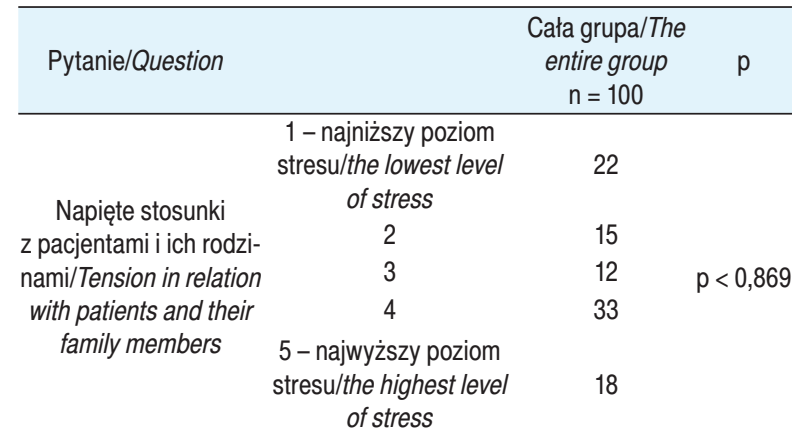




\begin{tabular}{|c|c|c|c|}
\hline \multirow{5}{*}{$\begin{array}{l}\text { Zła atmosfera/ } \\
\text { Bad atmosphere }\end{array}$} & $\begin{array}{l}1 \text { - najniższy poziom } \\
\text { stresu/the lowest level }\end{array}$ & 19 & \multirow{5}{*}{$p<0,981$} \\
\hline & 2 & 13 & \\
\hline & 3 & 20 & \\
\hline & 4 & 18 & \\
\hline & $\begin{array}{c}5 \text { - najwyższy poziom } \\
\text { stresulthe highest level } \\
\text { of stress }\end{array}$ & 30 & \\
\hline \multirow{5}{*}{$\begin{array}{c}\text { Niepewność zatrud- } \\
\text { nienia/ } \\
\text { Job uncertainty }\end{array}$} & $\begin{array}{c}1 \text { - najniższy poziom } \\
\text { stresu/the lowest level } \\
\text { of stress }\end{array}$ & 21 & \multirow{5}{*}{$\mathrm{p}<0,367$} \\
\hline & 2 & 15 & \\
\hline & 3 & 25 & \\
\hline & 4 & 18 & \\
\hline & $\begin{array}{l}\text { 5- najwyższy poziom } \\
\text { stresu/the highest level } \\
\text { of stress }\end{array}$ & 21 & \\
\hline \multirow{5}{*}{$\begin{array}{c}\text { Niskie wynagrodzenie/ } \\
\text { Low wages }\end{array}$} & $\begin{array}{c}1 \text { - najniższy poziom } \\
\text { stresu/the lowest level } \\
\text { of stress }\end{array}$ & 6 & \multirow{5}{*}{$\mathrm{p}<0,435$} \\
\hline & 2 & 6 & \\
\hline & 3 & 17 & \\
\hline & 4 & 28 & \\
\hline & $\begin{array}{c}5 \text { - najwyższy poziom } \\
\text { stresulthe highest level } \\
\text { of stress }\end{array}$ & 43 & \\
\hline \multirow{5}{*}{$\begin{array}{c}\text { Zła organizacja pracy/ } \\
\text { Poor organisation of } \\
\text { work }\end{array}$} & $\begin{array}{c}1 \text { - najniższy poziom } \\
\text { stresu/the lowest level } \\
\text { of stress }\end{array}$ & 9 & \multirow{5}{*}{$p<0,134$} \\
\hline & 2 & 13 & \\
\hline & 3 & 29 & \\
\hline & 4 & 23 & \\
\hline & $\begin{array}{c}5 \text { - najwyższy poziom } \\
\text { stresu/the highest level } \\
\text { of stress }\end{array}$ & 26 & \\
\hline \multirow{5}{*}{$\begin{array}{c}\text { Brak potrzebnych do } \\
\text { pracy środków i urzą- } \\
\text { dzeń/ } \\
\text { Lack of means and } \\
\text { facilities necessary for } \\
\text { work }\end{array}$} & $\begin{array}{c}1 \text { - najniższy poziom } \\
\text { stresu/the lowest level } \\
\text { of stress }\end{array}$ & 12 & \multirow{5}{*}{$p<0,645$} \\
\hline & 2 & 11 & \\
\hline & 3 & 23 & \\
\hline & 4 & 25 & \\
\hline & $\begin{array}{c}5 \text { - najwyższy poziom } \\
\text { stresulthe highest level } \\
\text { of stress }\end{array}$ & 29 & \\
\hline \multirow{5}{*}{$\begin{array}{l}\text { Złe relacje z przełożo- } \\
\text { nymi/ } \\
\text { Poor relations with } \\
\text { superiors }\end{array}$} & $\begin{array}{c}1 \text { - najniższy poziom } \\
\text { stresu/the lowest level } \\
\text { of stress }\end{array}$ & 26 & \multirow{5}{*}{$\mathrm{p}<0,079$} \\
\hline & 2 & 25 & \\
\hline & 3 & 18 & \\
\hline & 4 & 12 & \\
\hline & $\begin{array}{c}5 \text { - najwyższy poziom } \\
\text { stresu /the highest level } \\
\text { of stress }\end{array}$ & 19 & \\
\hline
\end{tabular}

p - poziom istotności różnic pomiędzy badanymi grupami pielęniarek w zależności od stażu pracy/level of significance of differences between study subgroups of nurses by length of service

Źródło: opracowanie własne

Source: author's own analysis

Większość badanych (56\%) deklarowała, że pielęgniarki w pracy często spotykają się z przemocą. Szczegółowe dane dotyczące występowania przemocy oraz jej form w pracy zawodowej w badanej grupie pielęgniarek przedstawia tabela 4.
Tabela 4. Występowanie oraz formy przemocy w pracy zawodowej $w$ badanej grupie pielęgniarek

Table 4. Incidence and forms of violence at work among the study group of nurses

\begin{tabular}{|c|c|c|c|}
\hline Pytanie/Question & & $\begin{array}{c}\text { Cała grupa/ } \\
\text { The entire } \\
\text { group } \\
\mathrm{n}=100\end{array}$ & I \\
\hline $\begin{array}{l}\text { Przemoc w pracy pielegniarki/ } \\
\text { Violence at work }\end{array}$ & $\begin{array}{l}\text { tak/yes } \\
\text { nie/no }\end{array}$ & $\begin{array}{l}56 \\
44\end{array}$ & $p<0,265$ \\
\hline $\begin{array}{l}\text { Pacjenci jako sprawcy przemocy/ } \\
\text { Patients as aggressors }\end{array}$ & $\begin{array}{l}\text { tak/yes } \\
\text { nie/no }\end{array}$ & $\begin{array}{l}37 \\
63\end{array}$ & $p<0,892$ \\
\hline $\begin{array}{c}\text { Krewni pacjentów jako sprawcy } \\
\text { przemocy/Patients' family members } \\
\text { as aggressors }\end{array}$ & $\begin{array}{l}\text { tak/yes } \\
\text { nie/no }\end{array}$ & 19 & $p<0,169$ \\
\hline $\begin{array}{l}\text { Przełożeni jako sprawcy przemocy/ } \\
\text { Superiors as aggressors }\end{array}$ & $\begin{array}{l}\text { tak/yes } \\
\text { nie/no }\end{array}$ & $\begin{array}{l}12 \\
88\end{array}$ & $p<0,273$ \\
\hline $\begin{array}{l}\text { Współpracownicy jako sprawcy prze- } \\
\text { mocy/Colleagues as aggressors }\end{array}$ & $\begin{array}{l}\text { tak/yes } \\
\text { nie/no }\end{array}$ & $\begin{array}{l}11 \\
89\end{array}$ & $p<0,454$ \\
\hline $\begin{array}{c}\text { Agresywne lub wulgarne zachowanie } \\
\text { pacjentów/ } \\
\text { Aggressive or vulgar behaviour of } \\
\text { patients }\end{array}$ & $\begin{array}{l}\text { bardzo często/ } \\
\text { very often } \\
\text { często/often } \\
\text { sporadycznie/ } \\
\text { rarely } \\
\text { nigdy/never }\end{array}$ & $\begin{array}{l}20 \\
29 \\
38\end{array}$ & $p<0,754$ \\
\hline
\end{tabular}

p - poziom istotności różnic pomiędzy badanymi grupami pielęgniarek w zależności od stażu pracy/level of significance of differences between study subgroups of nurses by length of service

Źródło: opracowanie własne

Source: author's own analysis

Większość badanych (58\%) deklarowała, że pielęgniarki w pracy często spotykają się z mobbingiem. Szczegółowe dane dotyczące występowania mobbingu oraz jej form w pracy zawodowej w badanej grupie pielęgniarek przedstawia tabela 5.

Tabela 5. Występowanie oraz formy mobbingu w pracy zawodowej w badanej grupie pielęgniarek

Table 5. Incidence and forms of mobbing at work among the study group of nurses

\begin{tabular}{|c|c|c|c|}
\hline Pytanie/Question & & $\begin{array}{c}\text { Cała } \\
\text { grupa/ } \\
\text { The entire } \\
\text { group } \\
\mathrm{n}=100\end{array}$ & $\mathrm{p}$ \\
\hline $\begin{array}{c}\text { Mobbing w pracy pielęgniarki/ } \\
\text { Mobbing at work }\end{array}$ & $\begin{array}{l}\text { tak/yes } \\
\text { nie/no }\end{array}$ & $\begin{array}{l}58 \\
42\end{array}$ & $\mathrm{p}<0,029$ \\
\hline $\begin{array}{l}\text { Nieuzasadniona ciągła krytyka pracy/ } \\
\text { Unjustified constant criticism }\end{array}$ & $\begin{array}{l}\text { tak/yes } \\
\text { nie/no }\end{array}$ & $\begin{array}{l}30 \\
70\end{array}$ & $p<0,324$ \\
\hline $\begin{array}{l}\text { Rozpowszechnianie plotek i pomówień/ } \\
\text { Dissemination of rumours and slander }\end{array}$ & $\begin{array}{l}\text { tak/yes } \\
\text { nie/no }\end{array}$ & $\begin{array}{l}31 \\
69\end{array}$ & $\mathrm{p}<0,692$ \\
\hline $\begin{array}{l}\text { Traktowanie , jak powietrze"/ } \\
\text { "Looking through" }\end{array}$ & $\begin{array}{l}\text { tak/yes } \\
\text { nie/no }\end{array}$ & $\begin{array}{l}14 \\
84\end{array}$ & $p<0,377$ \\
\hline Obraźliwe słowa/Insulting words & $\begin{array}{l}\text { tak/yes } \\
\text { nie/no }\end{array}$ & $\begin{array}{l}10 \\
90\end{array}$ & $p<0,387$ \\
\hline
\end{tabular}

$\overline{p-p o z i o m ~ i s t o t n o s ́ c i ~ r o ́ z ̇ n i c ~ p o m i e ̨ d z y ~ b a d a n y m i ~ g r u p a m i ~ p i e l e ̨ g n i a r e k ~ w ~ z a-~}$ leżności od stażu pracy/level of significance of differences between study subgroups of nurses by length of service

Źródło: opracowanie własne

Source: author's own analysis 
Większość badanych (65\%) deklarowała, że odczuwa bóle kręgosłupa z powodu stresu w pracy zawodowej. Szczegółowe dane dotyczące występowania określonych objawów stresu w pracy zawodowej w badanej grupie pielęgniarek przedstawia tabela 6.

Tabela 6. Objawy stresu w pracy występujące w badanej grupie pielęgniarek

Table 6. Symptoms of stress at work among the study group of nurses

\begin{tabular}{cccc}
\hline Pytanie/Question & \multicolumn{3}{c}{$\begin{array}{c}\text { Cała grupa/ } \\
\text { The entire } \\
\text { group } \\
n=100\end{array}$} \\
\hline Bóle kręgosłupa/Back pain & $\begin{array}{c}\text { tak/yes } \\
\text { nie/no }\end{array}$ & 35 & $\mathrm{p}<0,152$ \\
Dolegliwości gastryczne/Gastrointestinal & tak/yes & 18 & $\mathrm{p}<0,303$ \\
complaints & nie/no & 82 & $\mathrm{c}$ \\
Zwiększone ciśnienie krwi//ncreased & tak/yes & 26 & $\mathrm{p}<0,286$ \\
blood pressure & nie/no & 74 & \\
Wzrost aktywności gruczotów potowych/ & tak/yes & 25 & $\mathrm{p}<0,495$ \\
Increased sweat gland activity & nie/no & 75 & \\
Silne zmęczenie/Severe tiredness & tak/yes & 43 & $\mathrm{p}<0,338$ \\
& nie/no & 57 & \\
Częste przeziębienia/Frequent colds & tak/yes & 16 & $\mathrm{p}<0,600$ \\
& nie/no & 84 & \\
Problemy ze snem/Sleeping disorders & tak/yes & 34 & $\mathrm{p}<0,530$ \\
Trudności w koncentracji/Problems with & tak/yes & 66 & \\
concentration & nie/no & 72 & $\mathrm{p}<0,310$ \\
\hline
\end{tabular}

p - poziom istotności różnic pomiędzy badanymi grupami pielęgniarek w zależności od stażu pracy/level of significance of differences between study subgroups of nurses by length of service

Źródło: opracowanie własne

Source: author's own analysis

Tylko 31\% badanych pielęgniarek deklarowało, że podejmuje działania mające na celu zmniejszenie stresu. Szczegółowe dane dotyczące podejmowania działań mających na celu zmniejszenie stresu w pracy zawodowej w badanej grupie pielęgniarek przedstawia

\section{tabela 7.}

Tabela 7. Podejmowanie działań mających na celu zmniejszenie stresu w pracy w badanej grupie pielęgniarek

Table 7. Actions taken to reduce stress at work among the study group of nurses

\begin{tabular}{|c|c|c|c|}
\hline Pytanie/Question & & $\begin{array}{l}\text { Cała grupa/ } \\
\text { The entire } \\
\text { group } \\
\mathrm{n}=100\end{array}$ & $p$ \\
\hline $\begin{array}{c}\text { Podejmowanie działań mających } \\
\text { na celu zmniejszenie stresu/Actions } \\
\text { taken to reduce stress }\end{array}$ & $\begin{array}{l}\text { tak/yes } \\
\text { nie/no }\end{array}$ & 31 & $p<0,614$ \\
\hline $\begin{array}{l}\text { Szukanie pomocy u przełożonych/ } \\
\text { Looking for help from superiors }\end{array}$ & $\begin{array}{l}\text { tak/yes } \\
\text { nie/no }\end{array}$ & $\begin{array}{l}20 \\
80\end{array}$ & $p<0,088$ \\
\hline $\begin{array}{l}\text { Szukanie pomocy u współpracow- } \\
\text { ników/ } \\
\text { Looking for help from colleagues }\end{array}$ & $\begin{array}{l}\text { tak/yes } \\
\text { nie/no }\end{array}$ & $\begin{array}{l}34 \\
66\end{array}$ & $p<0,004$ \\
\hline
\end{tabular}

\begin{tabular}{|c|c|c|c|}
\hline $\begin{array}{l}\text { Szukanie pomocy u znajomych spoza } \\
\text { miejsca pracy/ } \\
\text { Looking for help from friends outside } \\
\text { of work }\end{array}$ & tak/yes & 61 & $p<0,300$ \\
\hline \multirow{2}{*}{$\begin{array}{l}\text { Szukanie pomocy u specjalisty/ } \\
\text { Looking for help from a specialist }\end{array}$} & tak/yes & 9 & \multirow{2}{*}{$\mathrm{p}<0,319$} \\
\hline & nie/no & 91 & \\
\hline \multirow{2}{*}{$\begin{array}{l}\text { Nieszukanie pomocy/Not looking } \\
\text { for help }\end{array}$} & tak/yes & 20 & \multirow{2}{*}{$\mathrm{p}<0,240$} \\
\hline & nie/no & 80 & \\
\hline
\end{tabular}

p - poziom istotności różnic pomiędzy badanymi grupami pielęgniarek w zależności od stażu pracy/level of significance of differences between study subgroups of nurses by length of service

Źródło: opracowanie własne

Source: author's own analysis

Większość badanych (65\%) deklarowała, że jednym z najczęstszych sposobów radzenia sobie ze stresem jest palenie papierosów. Szczegółowe dane dotyczące sposobów radzenia sobie ze stresem występującym w pracy zawodowej $\mathrm{w}$ badanej grupie pielęgniarek przedstawia tabela 8 .

Tabela 8. Sposoby radzenia sobie ze stresem w pracy w badanej grupie pielęgniarek

Table 8. Ways of dealing with stress at work among the study group of nurses

\begin{tabular}{|c|c|c|c|}
\hline Pytanie/Question & & $\begin{array}{c}\text { Cała grupa/ } \\
\text { The entire } \\
\text { group } \\
\mathrm{n}=100\end{array}$ & $\mathrm{p}$ \\
\hline Palenie papierosów/Smoking & $\begin{array}{c}\text { tak/yes } \\
\text { nie/no }\end{array}$ & $\begin{array}{l}65 \\
35\end{array}$ & $p<0,642$ \\
\hline Nadużywanie alkoholu/Alcohol abuse & $\begin{array}{l}\text { tak/yes } \\
\text { nie/no }\end{array}$ & $\begin{array}{c}8 \\
92\end{array}$ & $p<0,925$ \\
\hline Objadanie się/Overeating & $\begin{array}{l}\text { tak/yes } \\
\text { nie/no }\end{array}$ & $\begin{array}{l}29 \\
71\end{array}$ & $\mathrm{p}<0,199$ \\
\hline $\begin{array}{l}\text { Stosowanie technik relaksacyjnych/ } \\
\text { Relaxation techniques }\end{array}$ & $\begin{array}{l}\text { tak/yes } \\
\text { nie/no }\end{array}$ & $\begin{array}{l}22 \\
78\end{array}$ & $p<0,202$ \\
\hline $\begin{array}{c}\text { Zażywanie kąpieli z aromaterapią/Baths } \\
\text { with aromatherapy }\end{array}$ & $\begin{array}{l}\text { tak/yes } \\
\text { nie/no }\end{array}$ & $\begin{array}{l}21 \\
79\end{array}$ & $\mathrm{p}<0,841$ \\
\hline Uprawianie sportu/Sports activity & $\begin{array}{l}\text { tak/yes } \\
\text { nie/no }\end{array}$ & $\begin{array}{l}23 \\
77\end{array}$ & $p<0,674$ \\
\hline
\end{tabular}

p - poziom istotności różnic pomiędzy badanymi grupami pielęgniarek w zależności od stażu pracy/level of significance of differences between study subgroups of nurses by length of service

Źródło: opracowanie własne

Source: author's own analysis

\section{Dyskusja}

W prezentowanej pracy podjęto próbę oceny występowania stresu w grupie zawodowej pielęgniarek zatrudnionych w Samodzielnym Publicznym Szpitalu Klinicznym im. prof. Witolda Orłowskiego w Warszawie. Pomimo tego, że stres w zawodzie pielęgniarki stanowi ważny problem, nie odnaleziono artykułów omawiających i badania tego zagadnienia przeprowadzone z wykorzystaniem standaryzowanych narzędzi badawczych, takich jak: Skala Odczuwanego Stresu (PSS-10) 
oraz Inwentarz do Pomiaru Radzenia Sobie ze Stresem (Mini Cope).

Jak wskazują przeprowadzone badania, pielęgniarki każdego dnia są narażone na stres. Ponadto ankietowane pielęgniarki prawie jednogłośnie uznały, że praca, którą wykonują, jest stresująca.

Natomiast jeśli chodzi o radzenie sobie ze stresem, pielęgniarki stosowały wybrane strategie: koncentrowały się nad daną sytuacją, podejmowały dodatkowe działania, starały się wypracować metodę lub plan działania. Natomiast prawie nigdy w pracy zawodowej badane pielęgniarki nie wykorzystywały strategii: zaprzeczania zaistniałej sytuacji, picia alkoholu, rezygnacji z osiągnięcia określonego celu, traktowania zaistniałej sytuacji w sposób zabawny.

W dostępnej literaturze nie odnaleziono badań wykorzystujących narzędzia: Skalę Odczuwanego Stresu (PSS - 10) oraz Inwentarz do Pomiaru Radzenia Sobie ze Stresem (Mini Cope), w związku z tym dyskusja uzyskanych wyników będzie się opierać przede wszystkim na przybliżeniu doniesień polskich autorów, którzy korzystali z innych narzędzi badawczych, ale również chcieli ukazać występujące zjawisko stresu zawodowego w pracy pielęgniarki.

Perek i wsp. [3] z Zakładu Pielęgniarstwa Klinicznego Instytutu Pielęgniarstwa i Położnictwa WNoZ Collegium Medicum UJ w Krakowie analizowali wyniki badań uzyskanych z Kwestionariusza CISS (wykorzystywany do badania trudnych sytuacji) oraz Kwestionariusza Wsparcia Emocjonalnego. Badaniem objęto 108 pielęgniarek pracujących w oddziałach pediatrycznych w województwie małopolskim. Na podstawie przeprowadzonych badań można stwierdzić, że w pracy pielęgniarek pediatrycznych istnieje wiele trudnych sytuacji, wynikają one ze złej organizacji i fizycznych warunków pracy oraz relacji interpersonalnych w zespole. Do przyczyn występowania sytuacji trudnych badane pielęgniarki zaliczyły: niskie zarobki, odpowiedzialność za zdrowie i życie pacjenta, nieproporcjonalną liczbę obowiązków w stosunku do obsady pielęgniarek, lęk przed popełnieniem nieodwracalnego błędu, możliwość zakażenia, zagrożenie bezpieczeństwa osobistego, brak właściwej współpracy między grupami zawodowymi. Trudne sytuacje wywoływały u badanych pielęgniarek reakcje fizyczne, psychiczne oraz zmiany w zachowaniu. Spośród fizycznych reakcji organizmu ankietowane pielęgniarki wymieniły: bóle karku i ramion, kołatanie serca, wzmożone pocenie. Spośród objawów psychicznych respondentki wymieniły: zmęczenie i wyczerpanie, poczucie rozdrażnienia i nerwowość. Zmiany w zachowaniu pielęgniarki określiły jako: impulsywność działania, nadpobudliwość ruchową oraz konfliktowość. W strategiach radzenia sobie ze stresem badane pielęgniarki stosowały konstruktywne sposoby, które polegały na podejmowaniu wysiłków zmierzających do rozwiązania problemu przez poznawcze przekształcenia bądź próby zmiany sytuacji. Wiek i staż pracy wpływały na sposób radzenia sobie ze stresem. Im młodsza badana pielęgniarka, tym silniejszy styl emocjonalny, natomiast im większy staż pracy, tym słabszy styl emocjonalny. Staż pracy oraz wiek badanych pielęgniarek wpływały na liczbę czynników stresogennych w pracy [3].

Podobne wyniki uzyskano w badaniach Gułag [4]. W badaniu wzięło udział 100 pielęgniarek pracujących w oddziałach kardiologii i intensywnej opiece kardiologicznej w pięciu miastach Polski południowo-wschodniej. W celu przeprowadzenia badań posłużono się metodą sondażu diagnostycznego. Przeprowadzone badania dowiodły, że pielęgniarki uznają swoje środowisko pracy za silnie stresujące. Ponad połowa badanych pielęgniarek przekroczyła przeciętny poziom stresu, gdzie skutki stresu mogą manifestować się zaburzeniami somatycznymi. Spośród sposobów odreagowania napięć badane pielęgniarki opowiedziały się za: kontaktem z bliską osobą, słuchaniem muzyki oraz kontaktem z naturą. W sytuacjach trudnych pielęgniarki zwracały się po pomoc do osoby bliskiej lub starały się rozwiązać problem samodzielnie, bardzo rzadko zwracały się o pomoc do przełożonego, co pozwala wnioskować o złych relacjach personalnych między przełożonymi a pracownikami. Badane pielęgniarki wykazały nikłą wiedzę na temat profesjonalnych technik rozładowujących stres [4].

W badaniach przeprowadzonych przez Kowalczuk i wsp. [7] z Zakładu Zintegrowanej Opieki Medycznej Uniwersytetu Medycznego w Białymstoku analizowano ocenę narażenia na stres i wypalenie zawodowe pielęgniarek pracujących w stacjonarnej opiece medycznej w zależności od miejsca pracy. W badaniu wzięły udział 102 pielęgniarki z województwa podlaskiego, metodą badawczą był sondaż diagnostyczny. Analiza przeprowadzonych badań wykazała, że $72,6 \%$ badanych pielęgniarek było narażonych na stres w miejscu pracy, natomiast występowanie stresu zależało od miejsca pracy. Najwyższy poziom wypalenia zawodowego odczuwały pielęgniarki pracujące na oddziale internistycznym [7].

Owczarek i wsp. [1] z Zakładu Psychologii Medycznej Warszawskiego Uniwersytetu Medycznego również prowadzili badania na temat wypalenia zawodowego u pielęgniarek pracujących w wybranych oddziałach szpitalnych. W badaniu wzięło udział 61 pielęgniarek ze stażem pracy 1-29 lat, pracujących w trzech oddziałach szpitalnych: oddziale wewnętrznym, szpitalnym oddziale ratunkowym oraz oddziale pooperacyjnym, metodą badawczą był sondaż diagnostyczny. Analiza przepro- 
wadzonych badań wykazała, że pielęgniarki (zwłaszcza pielęgniarki pracujące na oddziale wewnętrznym) są grupą zawodową szczególnie narażoną na występowanie syndromu wypalenia zawodowego. Badania wykazały również, że długość stażu pracy pielęgniarek ma wpływ na występowanie wypalenia zawodowego.

Ogińska i Zuralska [12] z Zakładu Pielęgniarstwa Społecznego i Promocji Zdrowia WNoZ Gdańskiego Uniwersytetu Medycznego przeprowadziły badania na temat wypalenia zawodowego wśród pielęgniarek pracujących w oddziałach neurologicznych. W badaniu wzięło udział 112 pielęgniarek pracujących na terenie Gdańska i Elbląga. W badaniach tych autorki zastosowały metodę sondażu diagnostycznego. Uzyskane wyniki wykazały występowanie objawów i zachowań typowych dla zespołu wypalenia zawodowego w badanej grupie pielęgniarek, 19,6\% badanych respondentek prezentowało objawy oraz zachowania wskazujące na wysoki poziom wypalenia zawodowego. Głównymi czynnikami sprzyjającymi wypaleniu były przewlekłe oraz nadmierne obciążenia, takie jak: bezradność, zagrożenie bezpieczeństwa osobistego, przeciążenie obowiązkami, obcowanie z cierpieniem i śmiercią. Natomiast czynnikami, które obniżają wydajność pracy, były: prowadzenie dokumentacji medycznej, niskie zarobki, zła organizacja pracy, brak sprzętu oraz praca w godzinach nocnych.

Nyklewicz i Krajewska-Kułak [13] z Zakładu Pielęgniarstwa Ogólnego Uniwersytetu Medycznego w Białymstoku oceniali nasilenie lęku oraz przygnębienia pielęgniarek w sytuacji śmierci pacjenta lub osoby bliskiej. W badaniu wzięło udział 100 pielęgniarek z wykształceniem licencjackim, były to studentki studiów magisterskich uzupełniających. Wszystkie respondentki były czynne zawodowo. Do przeprowadzenia badania użyto autorskiej Skali Samooceny Emocji wobec Śmierci oraz standaryzowanych kwestionariuszy: STAI, CISS, CECS oraz GHQ-12. Na podstawie przeprowadzonych badań ustalono, że zdecydowana większość pielęgniarek (74\%) przeżywa silny lęk związany ze śmiercią pacjenta bądź osoby bliskiej. Jedynie jedna piąta respondentek potrafi stosować zadaniowy model radzenia sobie ze stresem, natomiast $78 \%$ badanych pielęgniarek nieefektywnie reaguje na stres. Większość pielęgniarek (69\%) stosuje tłumienie gniewu, (72\%) depresji oraz (76\%) lęku jako sposób radzenia sobie ze stresem.

W badaniach Kliszcz i wsp. [14] z Katedry i Zakładu Medycyny Rodzinnej Akademii Medycznej w Gdańsku analizowano również poziom lęku i depresji u pielęgniarek oraz związek tych zmiennych z tendencją do kontroli negatywnych emocji. Autorzy analizowali wyniki badań uzyskanych z Kwestionariusza Skali Kontroli Emocji oraz Kwestionariusza Skali Lęku i Depresji, badaniem objęto 102 pielęgniarki. Na podstawie przeprowadzonych badań można stwierdzić tendencję do tłumienia emocji negatywnych, takich jak: lęk, gniew czy depresja; skłonność ta cechuje pielęgniarki o krótkim i średnim stażu pracy.

Suwała i wsp. z Instytutu Pielęgniarstwa i Położnictwa WNoZ Collegium Medicum przedstawili wyniki badań uzyskanych metodą sondażu diagnostycznego w grupie 216 pielęgniarek i 4 położnych zatrudnionych w szpitalach województwa małopolskiego. Analiza przeprowadzonych badań wykazała, że pielęgniarki w pracy były narażone na przemoc fizyczną i psychiczną. Do najczęstszych form przemocy należały: słowne obelgi (54\%), zastraszanie (32\%) oraz fizyczne ataki (26\%). Sprawcami powyższych incydentów w większości byli pacjenci.

Z badań przeprowadzonych przez Kowalczuk i wsp. [15] z Zakładu Zintegrowanej Opieki Medycznej Uniwersytetu Medycznego w Białymstoku wynika, że największymi źródłami stresu w pracy pielęgniarek były zachowania agresywne ze strony innych pielęgniarek (29\%), lekarzy (28\%), oraz zachowania wulgarne przełożonych w stosunku do pielęgniarek (25\%). Nasilenie zdenerwowania pielęgniarek było spowodowane używaniem podniesionego głosu przez pacjentów (100\%) oraz wulgarnymi zachowaniami przełożonych w stosunku do pielęgniarek (67\%). Populację badanych osób stanowiły 493 pielęgniarki pracujące w otwartej i zamkniętej opiece zdrowotnej na terenie województwa podlaskiego. Do przeprowadzenia badania użyto Kwestionariusza do Oceny Cech Pracy i Ogólnego Stanu Zdrowia GHQ 28.

Zdziebło i wsp. z Zakładu Onkologii i Pielęgniarstwa Onkologicznego Instytutu Pielęgniarstwa i Położnictwa WNoZ Uniwersytetu Humanistyczno-Przyrodniczego Jana Kochanowskiego w Kielcach i Zakładu Opieki Zdrowotnej w Skarżysku Kamiennej wykazali w swoich badaniach na temat mobbingu w środowisku pracy pielęgniarek, że pielęgniarki w swojej pracy narażone były na różne formy agresji. Z przeprowadzonych badań wynika, że 40,4\% badanych doświadczyło agresji w pracy, stwierdzono również statystyczną zależność skali mobbingu od wykształcenia $(82,2 \%$ pielęgniarki z wyższym wykształceniem) i miejsca pracy $(74,0 \%$ na oddziałach zabiegowych). Niepokojący był też fakt, że personel, który podnosił swoje kwalifikacje zawodowe i zdobywał wyższe wykształcenie, był bardziej narażony na działania dyskryminacyjne. Jako mobberów 83\% respondentek wskazało przełożonych, co może świadczyć o niedoskonałości zarządzania w tej grupie zawodowej. Badania przeprowadzono metodą sondażu diagnostycznego w grupie 198 losowo wybranych pielęgniarek pracujących w lecznictwie otwartym i zamkniętym województwa świętokrzyskiego. 
Kunecka i wsp. [16] z Instytutu Medycyny Pracy im. prof. Jerzego Nofera w Łodzi również przeprowadzili badania na temat skali zjawiska mobbingu wśród pielęgniarek. Badanie przeprowadzono metodą sondażu diagnostycznego z użyciem kwestionariusza ankiety, w badaniu wzięło udział 1578 pielęgniarek zatrudnionych w szczecińskich szpitalach. Analiza przeprowadzonych badań wykazała powszechność zjawiska mobbingu w grupie zawodowej pielęgniarek, jako mobbera badane pielęgniarki wskazały przełożonego (40\%).

\section{Wnioski}

1. W badanej grupie pielęgniarek stwierdzono średni poziom odczuwanego stresu.

2. Staż pracy badanych wpływał na odczuwanie stresu: pielęgniarki z krótszym stażem pracy istotnie częściej odczuwały stres.

3. W konfrontacji z trudnymi sytuacjami w pracy zawodowej badane pielęgniarki stosowały konstruktywne sposoby radzenia sobie ze stresem, które polegały na analizie i wypracowaniu określonych działań zmierzających do rozwiązania problemu.

4. Do najczęstszych przyczyn występowania stresu badana grupa pielęgniarek zaliczyła: dużą odpowiedzialność za życie i zdrowie pacjenta, pracę pod presją czasu, nadmiar prowadzonej dokumentacji, złą atmosferę w pracy oraz niskie wynagrodzenie.

5. W odreagowaniu napięć związanych z pracą pielęgniarki preferują negatywne sposoby radzenia sobie ze stresem, tj. palenie papierosów oraz objadanie się. Wykazują zaś nikłą wiedzę na temat profesjonalnych technik rozładowujących stres.

6. W sytuacjach trudnych pielęgniarki w większości zwracają się po pomoc do osoby bliskiej lub starają się samodzielnie rozwiązać problem, rzadko zwracają się z problemem do przełożonego, co pozwala wnioskować o złych kontaktach personalnych między pracownikami a przełożonymi.

\section{Piśmiennictwo}

1. Owczarek K, Olczyk K, Wojtowicz S. Badanie zjawiska wypalenia zawodowego u pielęgniarek pracujących w wybranych oddziałach szpitalnych. Med Dydak Wychow. 2009; 1: 28-36.

2. Gułag B. Sytuacje trudne w środowisku pracy pielęgniarek a umiejętność radzenia sobie z nimi. Zdr Publ. 2004; 114(3): 367-370.
3. Perek M, Kózka M, Twarduś K. Trudne sytuacje w pracy pielęgniarek pediatrycznych i sposoby radzenia sobie z nimi. Probl Piel. 2007; 14(4): 223-228.

4. Gułag B. Stres w pracy pielęgniarek. Mag Piel Położ. 2003; 1: 18-23.

5. Ździebło K, Kozłowska E. Mobbing w środowisku pracy pielęgniarek. Probl Piel. 2010; 18(2): 212-219.

6. Drabek M, Merecz D, Mościcka A. Skala narażenia na agresję w miejscu pracy pracowników służby zdrowia i sektora usług. Med Pracy. 2007; 58(4): 299-306.

7. Kowalczuk K, Zdańska A, Krajewska-Kułak E, Łukaszuk C, Van Damme-Ostapowicz K, Klimaszewska K et al. Stres w pracy pielęgniarek jako czynnik ryzyka wypalenia zawodowego. Probl Piel. 2011; 19(3): 307-313.

8. Wyderka M, Kowalska H, Szeląg E. Wypalenie zawodowe jako problem występujący wśród pielęgniarek. Piel Pol. 2009; 4(34): 265-275.

9. Rogala-Pawelczyk G, Walenciak R. Pielęgniarka i położna zawody ryzyka. Mag Piel Położ. 2007; 12: 6-7.

10. Cohen S, Kamarck T, Mermelstein R. Skala odczuwanego stresu - PSS-10. W: Juczyński Z, Ogińska-Bulik N. Narzędzia do pomiaru stresu i radzenia sobie ze stresem. Warszawa: Pracownia Testów Psychologicznych PTP; 2009.

11. Carver CS. Inwentarz do Pomiaru Radzenia Sobie ze Stresem - Mini COPE. W: Juczyński Z, Ogińska-Bulik N. Narzędzia do pomiaru stresu i radzenia sobie ze stresem. Warszawa: Pracownia Testów Psychologicznych PTP; 2009.

12. Ogińska J, Żuralska R. Wypalenie zawodowe wśród pielęgniarek pracujących na oddziałach neurologicznych. Probl Piel. 2010; 18(4): 435-442.

13. Nyklewicz W, Krajewska-Kułak E. Śmierć a emocje pielęgniarek - doniesienie wstępne. Probl Piel. 2008; 16(3): 248-254.

14. Kliszcz J, Nowicka-Sauer K, Sadowska A, Trzeciak B. Kontrola emocji a poziom lęku i depresji u pielęgniarek. Zdr Publ. 2004; 114(3): 346-349.

15. Kowalczuk K, Krajewska-Kułak E, Kułak W, Van Damme-Ostapowicz K, Klimaszewska K, Rolak H. Wpływ agresji na występowanie stresu w populacji pielęgniarek i położnych na terenie województwa podlaskiego. Probl Hig Epidemiol. 2010; 91(3): 444-450.

16. Kunecka D, Kamińska M, Karakiewicz B. Skala zjawiska mobbingu wśród pielęgniarek/pielęgniarzy zatrudnionych w szczecińskich szpitalach. Med Pracy. 2008; 59(3): 223-228.

Artykuł przyjęty do redakcji: 07.05.2016

Artykuł przyjęty do publikacji: 26.06.2016

Źródło finansowania: Praca nie jest finansowana z żadnego źródła. Konflikt interesów: Autorzy deklarują brak konfliktu interesów.
Adres do korespondencji:
Joanna Gotlib
ul. Żwirki i Wigury 61
02-091 Warszawa
tel.: 225720 490, fax: 225720491
e-mail: joanna.gotlib@wum.edu.pl
Zakład Dydaktyki i Efektów Kształcenia
Warszawski Uniwersytet Medyczny 